\title{
The struggle for recognition: Axel Honneth's contributions for a moral (and liberal) grammar of social conflicts
}

\author{
Facundo Calegari ${ }^{*}$
}

\begin{abstract}
“[...] one must necessarily consider the additional fact that subjects must, in some way, have already recognized each other even before the conflict"

Axel Honneth, in The Struggle for Recognition: the moral grammar of social conflicts.
\end{abstract}

\begin{abstract}
In the present article I will uphold that Honneth's version of the theory of recognition (as a logical consequence of Hegel's concept of 'Sittlichkeit') has relevant dimensions for the analysis of social conflicts and for the development of social theory in general. I will analyze the arguments in favor of a "normative" content for social theory and I will argue, following Honneth, that the main cause of conflict in the theory of recognition works as a critic of the classic model of conflict in modern social thought (the model of material "survival" in Machiavelli and Hobbes). Later, I will outline the core characteristics that this theory may acquire in the discussion of the communitarian possibilities in democratic life. Lastly, I will point out in the conclusions the main advantages and potentialities that the theory of recognition could eventually gain in every intellectual or political conversation that intent to engage current democratic shapes: in this sense, I think it is possible to affirm that this theory is a fundamental input in the task of shaping a liberal conception of social conflicts.

Keywords: recognition, identity, democracy, society, liberalism.
\end{abstract}

\section{Introduction}

The characterizations of machiavelian-hobbesian classical republicanism and the cosmovisions that, engaging the problems of the republic, addresses conflict as an essential feature for modern politics are truly consistent and broadly accepted in the community of those who analyze politics. Nevertheless, a significant number of exegetes of modern republicanism shows a systematic shortcoming that makes impossible any extended analysis about the roles of conflict in every process of social reproduction: most of the time, it seems to be a priority for this perspectives the elevation of conflict as an irreducible, univocal engine of everything that is possible

\footnotetext{
* Political Science major, assistant professor and independent researcher (Universidad de Buenos Aires). Email: facundocalegari@vahoo.com.ar.
} 
inside the limits of associated life. Anyway, it is possible to argue, in a theoretical and practical manner, the existence of other suggestive ways of talking about conflicts. A priori, any alternative should attempt to answer if the classical republican theories of conflict are constituted as an structural limit to the experience of politics or if they rather show an element of political community (conflict) that lives along but doesn't override other fundamental aspects of the legitimacy in social order: I am referring to recognition and cooperation, as suggested by Axel Honneth $(1996,1997)$.

As human beings and conscious subjects we owe a good part of our integrity to several forms of recognition or reciprocal approval by other human beings. This means that when we perceive that we are recognized by others like us, we believe that we are closer of personal self-development. On the contrary, when that same perception has a negative content we tend to think that the lack of recognition to our identity is so degrading that, at the end, represents the impossibility of our development as human beings. Here is when it becomes necessary to say that the lack of recognition do not end in the regular material "distribution" from modern political thought: it is mostly about ways of degradation directly associated to intersubjective, conscious and largely moral relations. Moreover, taking the argument further, it becomes valid the introduction of the following question: is it sufficient for a theory of justice, or even for a practical justice, to be limited to the ways in which societies distribute material goods? Any society that is able to maintain functional its pattern of "material" distribution will surely be confronted with the problem implied by many subjects or even groups not having the recognition they want for themselves. Underlying this idea there is an ethical principle arguing that every form of recognition is vital for democracy, if we agree to understand it as a way of life. And Axel Honneth thinks about democracy as such.

Between those who advocate the hermeneutic of Hegel's works there is a significant consensus on the importance of the "Phenomenology of the Spirit" (Phänomenologie des Geistes) (Hegel, 1993) as a corner stone of his thought. A substantial part of this consensus would also sustain that the so called "theory of 
recognition" ${ }^{1}$, the theoretical scheme of social conflicts based on the forms of moral recognition between human beings who share a common life, never exercised a significant relevance in Hegelian thought. The main reason for this could be found in the fact that Hegel's early works remained a long time in the shadow of the indisputable kingdom of the "Phänomenologie des Geistes", a much more sophisticated work in terms of method and abstraction which subsumed it all to the exam of self-consciousness and absolute spirit (Hegel, 1993). But Axel Honneth is located among those who would interpose a well-established objection to that trend, presenting his theory as an attempt to actualize Hegel's theory of right - in the Jena period or Jenaer Rechtsphilosophie - that pushes us to the challenge of re-reading social conflicts as ways of the struggle for human recognition in almost every of its expressions. Among many other things, this theory sustains that the careful lecture of these social signs would be useful in the task of reaffirming the ideal and the practice of an ethical life for society as a whole. It is not only about a defense of individuality, autonomy nor the integration of individuals to the democratic life, but also a representation of the chance of considering society -and social theory- from its inherent normativity. This means, from a normativity that understands as a basic premise two basic premises: first, the fact that associated life requires that every individual should have real chances to self-develop; and secondly, that every individual must be recognized by a basic felling of mutual esteem as a precondition for the formation of the identity.

Now, the theory of recognition finds a clear antecedent in the concept of 'Sittlichkeit' developed by Hegel in his early works. According to Hegel (1982), Sittlichkeit, means the sum of obligations, norms and social values to which human beings are attached in the context of common life. Normally translated as 'ethic life' or 'concrete ethics', it is a fact that this concept not only holds the Hegelian critic to the

\footnotetext{
${ }^{1}$ As Joel Anderson remarks in the introduction to the English edition of Honneth, Axel. "The Struggle for Recognition: the moral grammar of social conflicts", MIT Press, Great Britain, 1996, the concept of recognition will always be referred to the possession or concession of a specific status -both from an individual or from a sociological point of view. This is due to the fact that, in German, "recognition" (Anerkennung) means basically the attribution of certain characteristics or positive attributes. Also, the impossibility or denial of recognition will be understood as "disrespect" (Mißachtung).
} 
Kantian notion of 'Moralität' ${ }^{2}$ : its central features also present the conception of individuality not as a sheer sum of isolated atoms (Hegel thought that utilitarianism conceived individuality in such manner), but rather as a part in a wider relationship that shows how the individual and the community are merged in a basic organic way, in which every identity formation process requires a social component. In short, subjectivity is what it is according to the social and cultural identity assumed by individuals in common life. Indeed, the main feature implies a very simple idea in an analytical context, but also significantly powerful in its practical consequences. According to this, a subject needs interaction with others in the process of identity formation: associated life would be, in all possible dimensions, the chance of selfdevelopment through three main forms of recognition. In the first place, love (Liebe), that includes friendly and affective relationships; secondly, right (Recht), that includes the institutionalization of the norms of acceptance between human beings; and thirdly, solidarity (Solidarität), understood as the possibility for society to recognize all forms of subjective inputs to the whole set of share values. Altogether, these three forms of recognition would imply, ultimately, the subjective perception of selfconfidence, (Selbstvertrauen), self-respect (Selbstachtung) and self-esteem (Selbstshätzung). Without a doubt, it is a sort of theoretical temperament in which subjectivity is not about absolute isolation, but instead it is considered from an "intersubjective" approach according to the contributions of G. H. Mead (2009) and G. W. F. Hegel (1993).

Hereinafter, I will try to show that the theory of recognition in Axel Honneth's version contains relevant dimensions for the analysis of social conflicts and for the development of social theory in general. In the next paragraph I will analyze the arguments in favor of a normative content for social theory and how, according to Honneth, the main cause of conflicts becomes constituted as a critic of the classic

\footnotetext{
2 As Charles Taylor put it: "Societies refer to the theoretical 'value' formulations as their norms rather than to practices, when they are trying to make themselves over to meet an unrealized standard; e. $g$. they are trying to 'build socialism', or become fully 'democratic'. But these goals are, of course, of the domain of 'Moralität'. 'Sittlichkeit' presupposes that the living practices are an adequate 'statement' of the basic norms [...] Hence we see the importance of Hegel's insistence that the end sought by the highest ethics is already realized". Sandel, Michael. "Liberalism and its Critics", New York University Press, 1984, p. 185.
} 
model of conflict (the model of physical "survival" and material competition in the thought of Machiavelli, 1984a and 1984b; and Hobbes, 1994). Next, I will outline the main characteristics that this theory acquires regarding the discussion of the common possibilities in democratic life. In the conclusions, I will sustain that the advantages related to the theory of recognition could eventually become powerful in every intellectual or practical conversation that intends to engage the shapes of democracy in our times: in this sense, I think it is possible to say that the theory of recognition is a fundamental piece of work in the task of achieving a liberal conception of social conflicts.

\section{Two fundamental features in the theory of recognition: normativity and the moral grammar of social conflicts}

One of the most important features within the social and political thought of Axel Honneth resides in the fact that his attempts to establish a corner stone in the construction of a normative theory made him recognize that the proper way to do it is on the basis of a "grammar" of social conflicts. In this attempt, the importance of selfdevelopment carried with itself normative dimensions that generally were marginalized by modern political thought. This is one of the most important aspects in Honneth's contribution to social theory, and I shall explain why.

When Honneth analyses at the classic political philosophy of Machiavelli and Hobbes, he concludes that those schemes had provided a set of intellectual temperaments to study social conflicts. Those temperaments are characterized by its complexity and variety, although in all of them the paradigm was dominated by the notion of a struggle for material and physical "survival", carrying within a negative conception of man, which is supposed to be considered selfish and violent by nature. The breakthrough of modern political philosophy inside the thought of Niccolò Machiavelli had established a new mode of conceiving human nature: in it, man was placed as a pivot in every process of associated living, which ultimately meant an abrupt break in respect to the theological explanations prevailing until that time. It seems clear that, for Machiavelli, men share a common life because they have natural needs and not because of a social or more positive anthropology within humanity. To 
sum up, and if it is possible to broadly characterize that particular conception of men, it becomes necessary to realize that Machiavelli was thinking in a hostile nature of human beings ${ }^{3}$, giving place to what Leo Strauss called "the context of the Machiavellian realism" (Strauss, 1972), in which a common and shared life becomes wrapped by the selfishness of men as a "natural base of politics" (Hilb, 2005). In his canonic work called "The Prince" (Machiavelli, 1984a), human nature seems to be connoted in regard to the volatility and ingratitude of men, and even in the Discorsi (Machiavelli, 1984b), this same general idea prevailed. Of course, this central feature of modern political philosophy, in which it becomes impossible to stop the evilness of mankind ${ }^{4}$, comes from the abrupt dissociation between human nature and its morals in the way it was known in the horizon of ancient politics -this is to say, the classic summum bonum in the thought of Plato and Epicure ${ }^{5}$. The evolution of political thought indicates that the renunciation of such hostile nature, as is expressed in the thought of Thomas Hobbes, is crucial for men to avoid that chaotic and violent world through the institution of the Leviathan, the biblical monster capable of maintaining men inside the limits of law and to provide the conditions for the reproduction of the political life (Hobbes, 1994).

But this modern tradition shows some controversial dimensions that in some cases are serious limitations: this is why Honneth was forced to justify his approach to a mode of conceiving social conflicts that emphasizes the analysis of mutual recognition. From Honneth's perspective, although in the works of Machiavelli and Hobbes it is clear that humanity is involved in a constant struggle for selfpreservation, that doesn't realize the fact that the contractual hypothesis -this is, the idea of a contract between individuals that puts an end to physical violence and makes

\footnotetext{
3 See, for instance, Michael Oakesshott, "Dr. Leo Strauss on Hobbes" (1937), in: Hobbes on Civil Association, Oxford, Basil Blackwell, 1975.

${ }^{4}$ The following passage clarifies this argument: "The Hobbesian understanding of political philosophy -of its necessity and possibility-implies a profound transformation of its purpose: it is now called to solve the problem of the human condition on earth, to solve the problem of the update of a just social ord er. In the classical view, the impossibility of the right order is, ultimately, inextricably linked to the impossible realization of the good: the cessation of evil is impossible", Hilb, ob. Cit. P. 140). Also, as a main characteristic of modern age, Strauss affirms that a "just city" is impossible by its own nature, simply because it becomes impossible to stop evilness: see, Strauss, Leo. The City and Man, Chicago, University of Chicago Press, 1978.

5 The dissociation of the classical summum bonum is mentioned by Leo Strauss in Natural Right and History, Chicago, University of Chicago Press, 1972.).
} 
it possible for men to start living in a legal and egalitarian society under the rule of the sovereign- contains some sorts of conflicts that are "grammatically" moral: starting from the Hegelian critic to the natural state and the contract among individuals, Honneth remarks that individuals necessarily have to recognize themselves and others even before the mere act of contracting. Individuals, in the context of that violent hostility that has been taking them to a constant antagonism of the natural state, recognize themselves even before the materialization of conflict, which supposes a kind of recognition of "the other" as a partner in action: "[...] conflict in the state of nature presupposes an implicit agreement between subjects, one that consists in the affirmation of the each other as partners to interaction" (Honneth, 1996:46) ${ }^{6}$.

Now, although the primary objective of Honneth isn't the rejection "in toto" of this materialistic way of conceiving conflicts that results as a consequence of the irruption of Machiavelli and Hobbes into the modern thought, his attempt wants to broaden the scope of this classic model by including some alternative dimensions for the consideration of conflict: it is here where it becomes possible the idea of a normative theory through the concept of "recognition" (Anerkennung). In this intellectual temperament, the early works of G. W. F. Hegel are crucial, mainly because his theory of individuality gets inserted in a context of constant struggle for the recognition of rights and solidarities that are relevant in every process of the individual's seek for autonomy ${ }^{7}$. Additionally, some contributions from the psychological theory of George Herbert Mead (2009) are complemented along with the Hegelian system to give shape to the central lines of Honneth's theory. In fact, the honnethian twist to a kind of "naturalism" present in Mead's thought turns to be vital

\footnotetext{
${ }^{6}$ It should be emphasized that the opportunities offered by Honneth in relation to the nature of social conflicts represents an additional dimension of signi ficant importance. The consideration of the moral grammar of social conflicts and the critics to the modern political philosophy of Machiavelli and Hobbes which follows from there also serves to locate Honneth's critic to the "materialism" of the Frankfurt School. According to Joel Anderson, in the introduction of the capital work of Honneth: "[...] the Frankfurt School suffered from an exclusive focus on the domain of material production as the locus of transformative critique. In the present volume, he now proposes and alternative account, situating the critical perception of injustice more generally within individuals' negative experiences of having their broadly 'moral' expectations violated". Ob. Cit. p. xi.

${ }^{7}$ One more time, Joel Anderson, clarifies the argument: "Honneth takes from Hegel the idea that full human flourishing is dependent of the existence of well established, 'ethical' relations -in particular, relations of love, law and 'ethical life' [Sittlichkeit]- which can only be established through a struggle for recognition", Ibid. p. 11.
} 
to get rid of the metaphysical and phenomenological aspects of Hegel's thought, achieving a "materialistic" anchorage that escapes from the philosophy of consciousness pursued by Hegel in his "Phenomenology" $(1993)^{8}$. Mead's thought acquires a significant worth because it emphasizes the importance of experience as a creative context in which human beings develop their practices and ideas. His social psychology carried a very novel "intersubjective" perception until it became the corner stone of a coherent and systemic theory. This particular way of thinking about psychosocial dimensions within society had exposed that individuals forge their practical identities depending, almost entirely, on the possibility of being recognized by others: this is how identity depends fundamentally on the adoption of those practical and common attitudes usually called "shared values". Social structure resides, then, in those habits that are the main explanation for the constitution for both individual and society (Mead, 2009:125-126).

It is a way of perceiving the identity formation process in which the principle of social organization is not "physiologic", or you may say, "mechanic", but rather reflects the outcome of the symbolic intercommunication and the human participation in the cultural legacy surrounding mankind. Furthermore, human communication gets installed in a universal speech that inhibits the existence of pure individual speeches and that supposes a large and varied amount of communications constituted through intersubjectivity, so the gestural exercise of language takes a relevant part in social life, specially because it was there where it was born and it is there where its "self" is (Mead, 2009). Even self-consciousness and its intrinsic relation with socialization became relevant for this way of conceiving the process of identity formation. And there, in the very core of social action, are located both individuality and community: above other aspects of Mead's thought, stands the way in which his social psychology

\footnotetext{
${ }^{8}$ Honneth is aware that under the shadow of the Phenomenology of Spirit, the possibilities of the theory of recognition were reduced to its minimum expressions: "[...] one would need to assume that the sort of intersubjectivist concept of 'ethical life' that, after Hegel's transition to a philosophy of consciousness is virtually completed is no longer available to him. [...] The Phenomenology of Spirit allots to the struggle for recognition -once the moral forces that drove the process of Spirit's socialization through each of its stages- the sole function of the formation of self-consciousness. Thus reduced to the single meaning represented in the dialectic of lordship and bondage, the struggle between subjects fighting for recognition then comes to be linked so closely to the experience of the practical acknowledgement of one's labor that its own particular logic disappears almost entirely from view". Ibid. p. 62-63.
} 
gives a practical component to the struggle for recognition that was suggested by Hegel. For instance, Honneth sees as it follows: "What re-emerged in Mead, in the altered form of an empirical hypothesis, was not only the general premise of the early Hegel -that practical identity-formation presupposes intersubjective recognition- but also postmetaphysical, naturalistic equivalents for the conceptual distinctions among various stages of recognition and even the wide-reaching assertion of a struggle mediating between these stages" (Honneth, 1996:92). Taken together, the contributions of Hegel and Mead constitute a practical and theoretical tool that allows the analysis of the conditions under which human beings produce and reproduce their own identities mediated by the logic of a "grammar" of social conflicts. Now I will summarize in the following paragraphs, although briefly taking into account more relevant goals, the three patterns of intersubjective recognition proposed by Honneth.

The theoretical elements found in Hegel and Mead allowed Honneth to shape a theory whose first attempt turns to be the description of cultural change and social conflicts as a result of the normative demands attached to mutual relations of recognition. Now, for such a theory to be useful in a hypothetical context -this is, a factual context- must necessarily be operational in relation to primary facts of associated living (a priori, it may be said that this was missing in Hegel and Mead). Honneth path's turns to be a triad of patterns of recognition: love (Liebe), right (Recht), and solidarity (Solidarität). In the first place, love (Liebe) is constituted for Honneth as a central dimension for individuals to express their needs and desires of experiencing primary relations, either friendship, erotic, or in its clearest example, the mother-son relationship ${ }^{9}$ : "[...] love represents the first stage of reciprocal recognition, because in it subjects mutually confirm each other with regard to the concrete nature of their needs and thereby recognize each other as needy creatures" (Honneth, 1996:95). This kind of relations represents a period in the identity formation process which denotes a fundamental human need that is reflected in the mandatory characteristic of any loving relation, and those relations are mandatory simply because

\footnotetext{
${ }^{9}$ This way of conceiving primary loving relations shows the influence of psychoanalytic theory inside Honneth's thought: "In the object-relations theory, conclusions are drawn, on the basis of the therapeutic analysis of relational pathologies, as to the conditions that can lead to a successful form of emotional attachment to other persons" (1996:96).
} 
their acceptance or rejection are fundamental for human identity. And under certain circumstances, the rejection of a relation of this kind means a severe violation, sometimes irreversible, to the rejected individual. Ultimately, this first pattern of recognition provides -or denies- the possibility of self-confidence (Selbstvertrauen), which supposes that individuals clinch their knowledge to themselves and to the others: in Hegel's view, it is about the chance of "the self in the other" (Hegel, 1982).

In the second place, right (Recht) represents the moment in which an individual recognizes the basic norms and obligations attached to society. Here, human beings recognize themselves as legal subjects, and legality supposes a set of obligations and responsibilities within the community: "[...] only once we have taken the perspective of the "generalized other", which teaches us to recognize the other members of the community as the bearers of rights, can we also understand ourselves to be legal persons, in the sense that we can be sure that certain of our claims will be met" (Honneth, 1996:108). From this point of view, individuals understand the legal system both as a result of the generalized recognition of the interests of the whole community and as related to a moral self-perception of a man facing the law. So, when an individual recognizes the relations between the rights and the responsibilities attached to those rights, it is possible to achieve self-respect (Selbstachtung), understood as a reciprocal dimension of the moral conscience of an individual.

In the third place, solidarity (Solidarität) represents a way of social valuation that is developed in a much more dense and deeper aspect of associated living, after love and right were recognized and achieved as such: "[...] in order to be able to acquire an undistorted relation-to-self, human subjects always need-over and above the experience of affectionate care and legal recognition- a form of social esteem that allows them to relate positively to their concrete traits and abilities" (Honneth, 1996:121). Solidarity, then, represents for Honneth the chance for individuals to participate in the cultural formation of their own time, developing their peculiarities and personal talents in the wider possible plenitude. This means that each individual must acknowledge that their contributions are considered positively, either by a social group in which the individual anchors their sense of solidarity or by the community as a macro-social instance. Given that, solidarity can be understood as the way individuals 
sympathize with the talents and abilities of their equals, contributing this way to the strengthening of the self-esteem (Selbstschätzung) necessary for their own dignity.

Now, a social theory that sets its foundation around the idea of a set of social conflicts that are linked directly to recognition requires, in turn, further considerations on the nature of democracy and community life. And it can be said that an important aspect of the normativity of this intellectual temperament lies unequivocally in its deeply ethical and communitarian conception of democratic life. In the following conclusions I will outline some definitions over the shapes and limits of such conception of democratic life.

\section{Conclusions: community and democracy in the political horizon of the theory of recognition}

From the previous analysis of Hegel's and Honneth's contributions one can easily state that democracy, according to both, is an ideal and a practice in which the universal goals of equality and individual self-development are forged in the patterns of intersubjective recognition of love, right and solidarity. What is more, Honneth shows his Hegelian influences to the extent that it ceases to conceive public life as the result of the classical constraints in the areas of autonomy and individual liberty ${ }^{10}$ and starts affirming the importance of organic "unity" under which liberty becomes possible for each individual. This conception of the unity within social life suggests that any systematic form of thought couldn't start by characterizing radically isolated individuals, but rather must begin with the moral ties that bind them together: "Thus, contrary to atomistic theories of society, one is to assume, as a kind of natural basis for human socialization, a situation in which elementary forms of intersubjective coexistence are always present" (Honneth, 1996:14)11. Indeed, Honneth emphasizes the imperative need for individuals to be consciously and

\footnotetext{
10 Probably, the best characterization of this way of conceiving liberty is to be found in one of the contemporary classics of liberal thought: Berlin, Isaiah. Four Essays on Liberty, (1990), Oxford University Press, USA.

${ }^{11}$ This eloquent Hegelian influence in Honneth is probably one of the most important signs that took John Dewey to the systematic appreciation of the "organic" theory within Hegel. For further analysis on this topic, see, for instance, Ryan, Alan. John Dewey and the High Tide of American Liberalism, Norton and Company, New York, 1997.
} 
cooperatively recognized as free and autonomous in every human and creative activity, including of course political life. There, in the "polis", individuals recognize themselves as concrete and specific human beings, and even the possibility of affecting recognition is to be considered as a heavy injury that impacts negatively on the perception they have over themselves: this means that, in the context of a common life, there are some stages of recognition and some stages of conflict, giving place to a contingent conception of society in which social relations are never represented in an "a-historic" manner but rather forged in the evolution of social conflicts and in their moral and institutional dimensions ${ }^{12}$.

But since the search for individual autonomy is in a constant tension with the areas of solidarity, the future of democratic reproduction needs to give shape to some sort of alignment between the two, a problem that shows the need for democratic experiences to give hope for cooperation. It may be redundant to recognize that the efforts to clarify the theoretical and practical foundations needed for democracy have been presented in a complex variety of intellectual attempts, often crystallized in practical or political demonstrations touting the need for reconstruction. However, it can be state that in most Western democracies these efforts turned around some dualist debates that had placed in opposite poles the proposals of classic republicanism and modern procedimentalism as dominant paradigms in the theory and practice of politics (Habermas, 1998). It might be added, bringing some sort of geographical and temporal perspective, that much of the Latin American countries have been defining socio-political problems through other parochial traditions, as in the case of populism ${ }^{13}$. Even though the fertility contained in such discussions, the fact is that the balance had resulted in a greatly simplified opposition in which prevails the idea that this antagonist poles are pretty much everything that could be said about democracy (Honneth and Farrell, 1998).

\footnotetext{
12 Once again, Joel Anderson seems to clarify an important dimension of the theory of recognition: "The grammar of such struggles is 'moral' in the sense that the feelings of outrage and indignation driving them are generated by the rejection of claims to recognition and thus imply normative judgments about the legitimacy of social arrangements. Thus, the normative ideal of a just society empirically is confirmed by historical struggles for recognition" Ibid. p. 12.

13 About the theoretical treatment of the concept of "populism", see, for instance, Germani, (1965), Collier/Collier (1991) and Laclau (2010).
} 
Following this judgment, Honneth's community reaffirm its conception on the basis of the social and political thought of John Dewey (1991), the owner of an intellectual and practical attitude that set the limits and contours of democracy in such a manner that becomes consistent with both republicanism and procedimentalism, and even overcomes them. This implies the fact that, in the context of a necessary reconstruction of the central dimensions of democracy as a "way of life", John Dewey theorized around the possibility of a type of democratic, even radically reformer liberalism, not only as an alternative to the communist scenario opened by the Russian Revolution in 1917, the Great Depression of the '30s or the successive post-war periods, but mainly in front of the historical drift of liberalism from its origins to the "individual-selfishness" within mercantilism (including, of course, the laissez faire). Works such as "The Public and its Problems" (1927), "Liberalism and Social Action"(1935), "Individualism Old and New" (1930) and "Freedom and Culture" (1939), among many others, reflect an intellectual attitude and a human predisposition that includes the reorganization of the community horizon on the basis of the practical and reflexive reconstruction of liberal democracy ${ }^{14}$.

John Dewey was in large part the political heir of a specific narrative of democracy primarily connoted by the transition, occurred in Great Britain, from classical to progressive liberalism. Alan Ryan, in one of the most important works on the social and political thought of John Dewey, recognizes this linkage in a concise manner: "[...] Dewey's political views were those of what in Britain was called advanced liberalism - politically radical, attached to the rights of women, attached to a secular state, siding with labor against capital, but not confiscatory, not 'impossibilist', not insurrectionary, and in the last resort non particularly socialist if by "socialism" we mean attaching great importance to public ownership and the abolition of private

\footnotetext{
14 Dewey's treatment of the concept of "public opinion" turns to be clarifying on this topic, since he defended the idea of a broaden democracy in a time in which the reproduction of western capitalism showed new ways of social control through, for example, mass consumption and mass media. In "The Public and its Problems", Dewey attacked the works of Walter Lippmann ("Public Opinion", published in 1922 and "The Phantom Public", published in 1925) in a well known and surely public debate: while Lippmann stated his skepticism over the constitution of a public opinion, Dewey argued that the possibilities of a public opinion will depend on the grounds of individualliberties and the promotion of a wider social control over democracy.
} 
property in the means of production" (Ryan, 1997:88). As a part of this democratic attitude, Dewey conceived that the main task of a new way of describing liberalism should appeal to "social intelligence" as a mean of human selfrealization, understood as well as one of the ultimate aims of democratic politics. After all, when Honneth says that Dewey aims his thought not to a model of "communicative deliberation", but to social cooperation (Honneth e Farrell, 1998), he accepts that the Deweyan conception of "social intelligence" 15 is clearly compatible with the theory of recognition, mainly as an alternative explanation of social and moral conflicts $^{16}$. Here becomes clear that, for both Honneth and Dewey, recognition plays an essential role inside the limits of associated life. Ultimately, both of them can claim that democracy is the democratic rule of men overmen themselves, while each individual contributes to the community and is being recognized by it according to the social value they bring to the common life. And it is also a form of description of social conflicts which states that the struggles for intersubjective recognition are the generators of the social pressures that are necessary for the establishment of institutions that would guarantee liberty in almost all its forms.

Finally, we must recognize that, in terms of the arguments presented here, there are several dimensions that would eventually be positive for the analysis of contemporary politics and its experience. The first of these dimensions is that the theory of recognition confronts us with the possibility of conceiving the process of identities formation as the ways in which societies identify conflicts and

\footnotetext{
15 In one of the most remarkable works about the life and mind of John Dewey, Sidney Hook linked the proposal of "social intelligence" with the most vital dimensions of democracy, as for instance the individual's participation in democratic life: "The wider use of organized intelligence is possible, therefore, only in a truly democratic society. It is possible in such a society because it provides major opportunities of mutual consultation, of active participation of all adult minds affected by social politics and of voluntary acceptance of proofs and control". Hook, Sydney. John Dewey: semblanza intelectual, Paidós, Barcelona, 2000, p. 114.

16 A special mention is needed about the republican model of deliberation that is involved in the previous paragraphs. Dewey would agree with Arendt and Habermas in a critique to the old canonic liberal individualism. But while Arent and Habermas argue that the collective will and individual liberty can only be achieved through various dimensions of communicative action and public deliberation, Dewey would rather emphasize than only in terms of a cooperative and intelligent form of political deliberation self-development could be achieved. At this level of cooperation and development of the social organism, Dewey finds that the public opinion is inherent to social life, considering not very useful to think of government as an isolated sphere, but rather as a "living expression" of the reflective forces representing cooperative interests. Honneth and Farrel, 1998: p., 8.
} 
imagine solutions. This implies the fact that the chances to re-semanticize the shapes of politics from a liberal perspective could be extended to certainly unknown places, yet to be explored. This also means that there is still an open possibility of achieving a new liberalism that could consider the semantic conditions of every liberal "moment" with the aim of building a social order derived from cooperation and social intelligence, giving place to the exercise of collective and communitarian resolution of social conflicts. John Dewey in his time and Axel Honneth in our own days invite us to be convinced, albeit cautiously, that among the variety of temperaments cohabitating the vast world of politics, the liberal temper can be extremely useful in any humble conversation that is attempting to contribute with the coordination of our life as partners. In short, in front of the question "can we nowadays uphold some kind of liberal faith?", the contributions of Axel Honneth and John Dewey leave us on a hopeful scenario.

\section{References}

Berlin, Isaiah. 1990. Four Essays on Liberty, Oxford University Press, USA.

Collier, Ruth B. and Collier, David. 1991. Shaping the Political Arena, Princeton University Press.

Dewey, John. 1991. The Collected Works of John Dewey, Southern Illinois University Press, first edition.

Germani Gino. 1965. Política y Sociedad en una época en transición: de la sociedad tradicional a la sociedad de masas, Editorial Paidós, Buenos Aires.

Habermas, Jürgen. 1998. Facticidad y validez. Madrid, Trotta.

Hilb, Claudia. 2005. Leo Strauss: el arte de leer. Una lectura de la interpretación straussiana de Maquiavelo, Hobbes, Locke y Spinoza, FCE, Buenos Aires.

Hegel, G. F. W. 1982. Sistema de la Eticidad, Editorial Nacional, España.

Hegel, G. F. W. 1993. Fenomenología del Espíritu, FCE, México.

Hobbes, Thomas. 1994. Leviatán, o la materia, forma y poder de una república eclesiástica y civil, FCE, Buenos Aires.

Honneth, Axel and Farrell, John M. M. 1998. "Democracy as Reflexive Cooperation: John Dewey and the Theory of Democracy Today", Political Theory, Vol. 26, No. 6 (Dec., 1998), pp. 763-783. 
Honneth, Axel. 1992. "Integrity and Disrespect: Principles of a Conception of Morality Based on the Theory of Recognition", Political Theory, Vol. 20, No. 2, 1992, pp. 187-201.

Honneth, Axel. 1996. The Struggle for Recognition: the moral grammar of social conflicts, MIT Press, Great Britain, Introduction by Joel Anderson.

Honneth, Axel. 1997. La lucha por el reconocimiento. Por una gramática de los conflictos sociales. Traducción española de Manuel Ballestero. Barcelona, Crítica.

Honneth, Axel. 2003. Kampf um Anerkennung. Sur moralischen Grammatik sozialer konflikte, Frnakfurt, Suhrkamp.

Hook, Sydney. 2000. John Dewey: semblanza intelectual, Paidós, Barcelona.

Fascioli, Ana. 2008. "Autonomía y reconocimiento en Axel Honneth: un rescate de El Sistema de la Eticidad de Hegel en la filosofía contemporánea", Revista ACTIO № 10-december 2008, Uruguay.

Laclau, Ernesto. 2010a. La razón populista. Fondo de Cultura Económica, Buenos Aires.

Laclau, Ernesto and Mouffe, Chantal. 2010b. Hegemonia y Estrategia Socialista. Hacia una radicalización de la democracia, FCE, Buenos Aires.

Machiavelli, Nicolo. 1984a. The Prince, Bentham Classics.

Machiavelli, Nicolo. 1984b. The Discourses, Penguin Classics.

Mead, G. H. 2009. Escritos Filosóficos y Políticos, introduction and preliminary study by Gregorio Kaminsky, FCE, Buenos Aires.

Michael Oakesshott, 1975. "Dr. Leo Strauss on Hobbes" (1937), in: Hobbes on Civil Association, Oxford, Basil Blackwell.

Ryan, Alan. 1997. John Dewey and the High Tide of American Liberalism, Norton and Company, New York.

Strauss, Leo. 1978. The City and Man, Chicago, University of Chicago Press.

Strauss, Leo. 1972. Natural Right and History, Chicago, University of Chicago Press.

Sandel, Michael. 1984. Liberalism and its Critics, New York University Press. 